\title{
SYNTHESIS AND REACTIONS OF 2-CHLOROVINYL SULFONES
}

\author{
J. Višngevska, E. Ābele
}

\author{
Latvian Institute of Organic Synthesis, 21 Aizkraukles Street, Riga, LV-1006, Latvia \\ e-mail: abele@osi.lv
}

Methods for the preparation of unsubstituted (E)-2-chlorovinyl sulfones are reviewed. Literature data on substitution of chlorine atom in 2-chlorovinyl sulfones leading to formation of different types of disubstituted ethenes are presented also. Synthesis of novel heterocyclic compounds directly from 2-chlorovinyl sulfones is also included in the present review.

Key words: 2-chlorovinyl sulfones, addition, radical 2-chlorovinylation, heterocycles

\section{INTRODUCTION}

Functionalized unsaturated sulfur-containing compounds are investigated widely as valuable intermediates in organic synthesis [1-3]. 2-Chlorovinyl sulfones, among them sulfur-containing compounds, are extensively investigated during last years. For example, 2-chlorovinyl sulfones exhibit high cytotoxic, antimicrobial [4], fungicidal [5] activities and are used in veterinary medicine and cosmetic compositions [6].

Synthesis and reactions of 2-chlorovinyl sulfones aren't reviewed till now and therefore is an aim of the present work. Transformations of different types of organic compounds bearing unsubstituted 2-chlorovinylsulfonyl group are included in this work.

\section{SYNTHESIS OF 2-CHLOROVINYL SULFONES}

2-Chlorovinyl sulfones are typically prepared by oxidation of 2-chlorovinyl sulfides [7] with $\mathrm{H}_{2} \mathrm{O}_{2}$ in $\mathrm{AcOH}[8,9], \mathrm{H}_{2} \mathrm{O}_{2} / \mathrm{AcOH} / \mathrm{H}_{2} \mathrm{SO}_{4}[10,11] \mathrm{H}_{2} \mathrm{O}_{2}$ / $\mathrm{AcOH} / \mathrm{Ac}_{2} \mathrm{O}$ [12] or $m$-chloroperbenzoic acid (m-CPBA) in $\mathrm{CH}_{2} \mathrm{Cl}_{2}$ [13]. We have recently described new and simple two-step method for the synthesis of 2-chlorovinyl sulfones $\mathbf{3}$ by oxidation of the corresponding 2-chlorovinyl sulfides 2, prepared by phase transfer catalytic alkylation of thiols $\mathbf{1}$ in the system solid $\mathrm{KI} /$ solid $\mathrm{K}_{2} \mathrm{CO}_{3}$ (then solid $\mathrm{KOH}$ ) / 18-crown-6 / PhMe [14, 15].

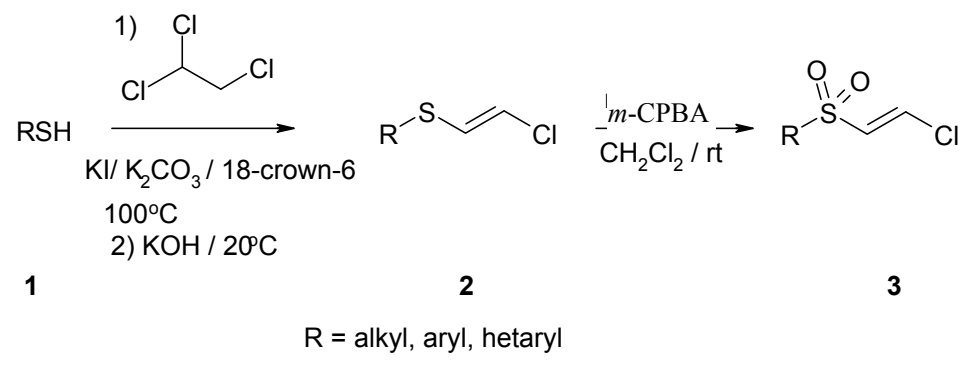


(E)-2-Chloroethenylphenyl sulfone (5) was prepared from benzenesulfanyl chloride 4 on treatment with acetylene and then oxidation with $m$-CPBA [11, 16]. Isomer $(Z)$ of compound 5 was easily obtained by decarboxylative chlorination of (Z)-3-(phenylsulfanyl)acrylic acid 6 followed by oxidation with $\mathrm{H}_{2} \mathrm{O}_{2}$. Similarly acid $E$-6 afforded stereoselectively $E$-isomer of 2-chlorovinyl sulfone 5 [10].
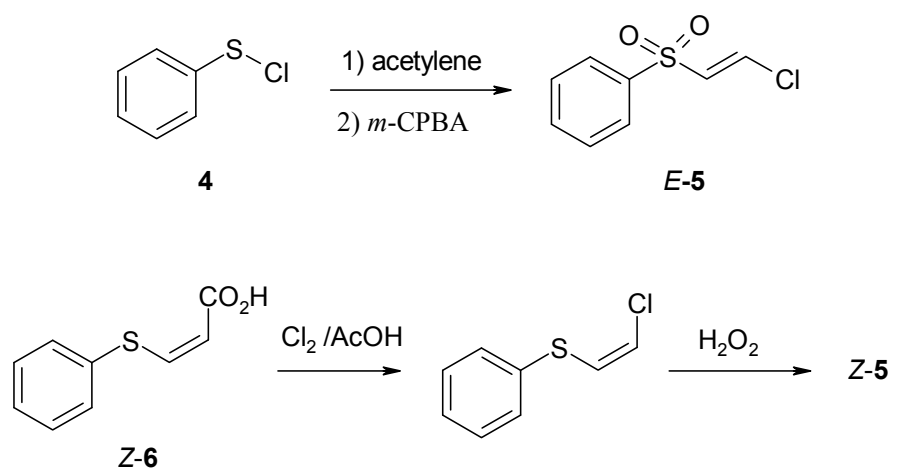

Two methods for the preparation of 2-chlorovinyl sulfones from the corresponding disulfides were presented in literature $[12,17]$. Thus, treatment of disulfide 7 with chlorine in $\mathrm{CCl}_{4}$ at room temperature and then with ethyl acetate leads to formation of vinyl derivative 8. Oxidation of compound with $m$-CPBA in $\mathrm{CH}_{2} \mathrm{Cl}_{2}$ afforded $E$-isomer of chlorovinyl sulfone 9. Sulfuryl chloride as chlorinating agent of disulfides was also used in the synthesis of $(E)-2-$ chlorovinyl sulfones [17].<smiles>O=[N+]([O-])c1ccc(SSc2ccc(S(=O)(=O)C=CCl)cc2)cc1</smiles>

Some methods of synthesis of 2-chlorovinyl sulfones from different sulfones or sulfonyl chlorides were presented. Thus, treatment of 2,2-dichloroethanesulfonylarenes with $\mathrm{Et}_{3} \mathrm{~N}[18,19], \mathrm{Et}_{3} \mathrm{~N} / \mathrm{PhH}$ [20-22] or $\mathrm{Et}_{3} \mathrm{~N} / \mathrm{CH}_{2} \mathrm{Cl}_{2}$ [23] selectively leads to formation only of $E$-isomers of 2-chlorovinyl sulfones. For example, reaction of 2,2-dichloroethanesulfonylbenzene (10) with $\mathrm{Et}_{3} \mathrm{~N}$ in mixture of diethyl ether and dichloromethane at $15{ }^{\circ} \mathrm{C}$ afforded product $(E)-5$ in $97 \%$ yield [24].

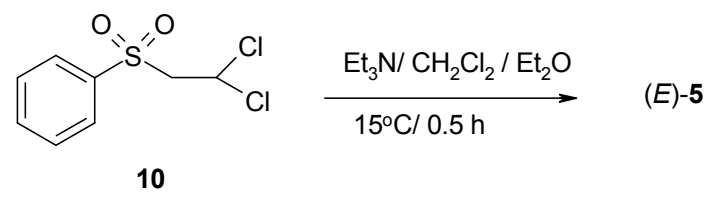


Treatment of benzene sulfonyl chloride (11) with naphthalene-1,4-diyldiamine hydrochloride in the presence of $\mathrm{AlCl}_{3}$ in chloroform and then with $\mathrm{Et}_{3} \mathrm{~N}$ afforded $(E)-5$ in $78 \%$ yield [21]. Interestingly, that treatment of ethynyl $p$-tolyl sulfone (12) with ethylaluminum dichloride in benzene leads to aluminated intermediate 13. Quenching the reaction mixture with $\mathrm{D}_{2} \mathrm{O}$ afforded deuterated product $\mathbf{1 4}$ in 58\% yield [25].

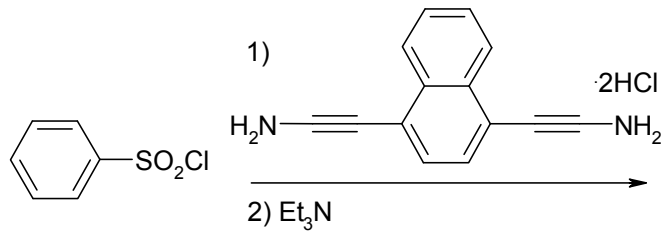

11

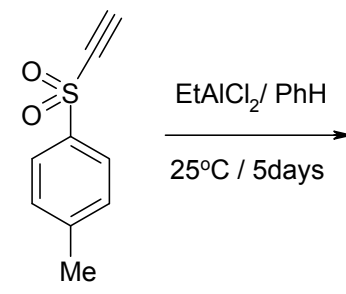

12

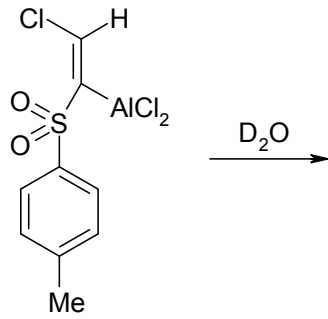

13<smiles>[2H]/C(=C\Cl)S(=O)(=O)c1ccc([N+](=O)[O-])cc1</smiles>

14

Some works were dedicated to synthesis of nitro [26], amino [27] and diazo [28] derivatives of 2-chlorovinyl sulfones. For example, reaction of amino derivative of sulfone 15 with $\mathrm{NaNO}_{2}$ in concentrated $\mathrm{HCl}$ and treatment of reaction mixture with $\mathrm{N}$-methyl-4-hydroxy-2-quinolone (16) and $\mathrm{NaOH}$ afforded diazo derivative of 2-chlorovinyl sulfone (17) [28].

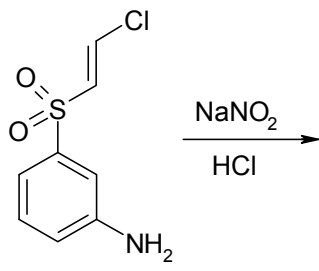

15<smiles>[R]n1c(=O)cc(C)c2ccccc21</smiles>

16<smiles>Cn1c(=O)c(N=Nc2cccc(S(=O)(=O)/C=C/Cl)c2)c(O)c2ccccc21</smiles>

17

Finally, isomerization of $Z$-isomer of $p$-nitrophenyl 2-chlorovinyl sulfone to the corresponding $E$-isomer readily proceeded in aqueous nitric acid in the presence of $\mathrm{NaNO}_{2}[10]$.

\section{REACTIONS OF 2-CHLOROVINYL SULFONES}

\section{Substitution of chlorine atom in 2-chlorovinyl sulfones}

Chlorine atom in 2-chlorovinyl sulfones was readily substituted by iodine atom [23] or hydroxyl group. Thus, treatment of compound $(E)-5$ with an excess of $\mathrm{NaI}$ in acetone at $130{ }^{\circ} \mathrm{C}$ afforded thr corresponding iodo derivative $\mathbf{1 8}$ in 
$76 \%$ yield. Reaction of 2-chlorovinyl sulfone 19 with aqueous $\mathrm{NaOH}$ lead to 2hydroxyvinyl sulfone 20 [19].

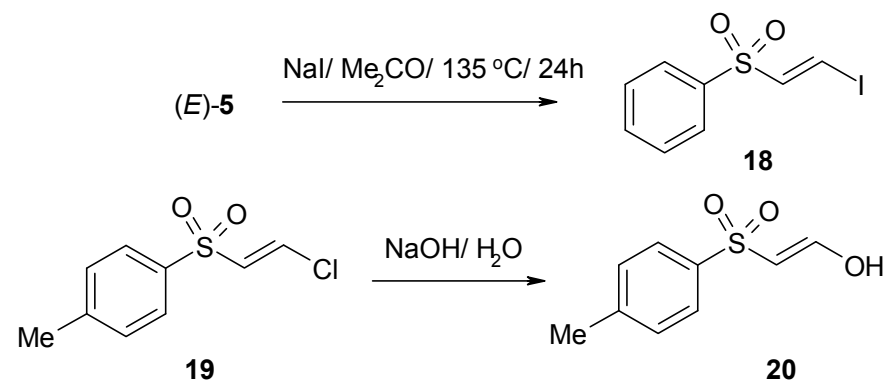

Some works were dedicated to conjugate addition of O-nucleophiles to 2chlorovinyl sulfones. The interaction of 2-chlorovinyl sulfones with sodium methylate is strongly influenced by amounts of this base. Generally, interaction of compounds 21 with $\mathrm{NaOMe}$ in $\mathrm{MeOH}$ leads to formation of mixture of mono- 22 and double addition products 23 [29]. Interaction of 2-chlorovinyl sulfone 5 with $\mathrm{MeOH}$, and then with $\mathrm{BuLi} / \mathrm{MeI}$ afforded (E)-2-methoxy-1methyl-1-(phenylsulfonyl)ethylene (24) [30].<smiles>[R]c1ccc(S(=O)(=O)/C=C/Cl)cc1</smiles>

21<smiles>[R]O/C=C/S(=O)(=O)c1ccc([R])cc1</smiles>

22<smiles>[R]c1ccc(S(=O)(=O)CC(OC)OC)cc1</smiles>

23

$\mathrm{R}=\mathrm{Cl}, \mathrm{Me}$

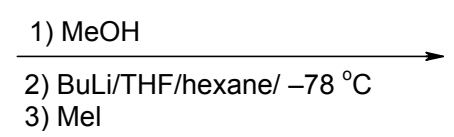<smiles>COC=C(C)S(=O)(=O)c1ccccc1</smiles>

$(E)-24$

Addition of different carboxylic acid derivatives to 2-chlorovinyl sulfone 9 was investigated in details in article [17]. It is interesting, that addition of 4,4dimethyl-3-hydroxypentanoic acid to compound $\mathbf{9}$ afforded only carboxylic group addition product 25 .<smiles>CCN(CC)CCCC(O)CC(=O)OC=CS(=O)(=O)c1ccc([N+](=O)[O-])cc1</smiles> 
Addition of different N-nucleophiles (primary and secondary amines) to 2chlorovinyl sulfones readily proceeded in $\mathrm{MeOH}$ [31], EtOH [31, 32], DMF [17], $\mathrm{MeCN}$ [33] and in the system $\mathrm{Cs}_{2} \mathrm{CO}_{3} /$ 18-crown-6 / PhMe [34]. Interaction of 2-chlorovinyl sulfone $\mathbf{5}$ with hydroxylamine in the mixture EtOH / $\mathrm{H}_{2} \mathrm{O}$ afforded hydroxylamine 26. Similarly hydrazine 27 [32] and azide 29 [35] derivatives were prepared from the corresponding chlorovinyl sulfones 9 and 28, correspondingly. 2-Chlorovinyl sulfones react also with tertiary amines forming the corresponding ammonium salts [33].<smiles>O=C(O)NOc1ccccc1S(=O)(=O)C=CNO</smiles><smiles>NN/C=C/S(=O)(=O)c1ccc([N+](=O)[O-])cc1</smiles>

$(E)-27$

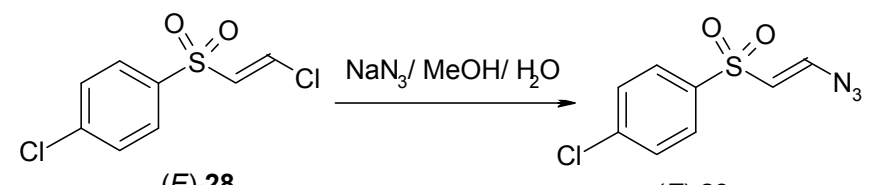

(E)-28

(E)-29

Some articles were dedicated to addition of S- and Se-nucleophiles to 2chlorovinyl sulfones. Thus, 2-mercaptoacetic acid undergoes addition to 2-chlorovinyl sulfine 5 in the presence of $\mathrm{NaOH}$ in EtOH. (E)-Phenylsulfonylethenemercaptoacetic acid (30) was isolated in $72 \%$ yield [36]. Reaction of 2chlorovinyl sulfones 31 with $\mathrm{Na}_{2} \mathrm{~S}$ in dioxane [37] or $\mathrm{MeOH}$ [38] afforded sulfides 32 in yields up to $90 \%$. Sulfinic acids and 2-chlorovinyl sulfones in the presence of $\mathrm{NaHCO}_{3}$ [32] or salts of sulfinic acids in $\mathrm{MeOH}$ [20] also gave the corresponding addition products. Phenylselenol was successfully added to 2chlorovinyl sulfones in the presence of $\mathrm{Et}_{3} \mathrm{~N} / \mathrm{PhH}$ [39], $\mathrm{Et}_{3} \mathrm{~N} / \mathrm{PhMe}$ [34] and $\mathrm{Cs}_{2} \mathrm{CO}_{3} /$ 18-crown-6 / PhMe [34].

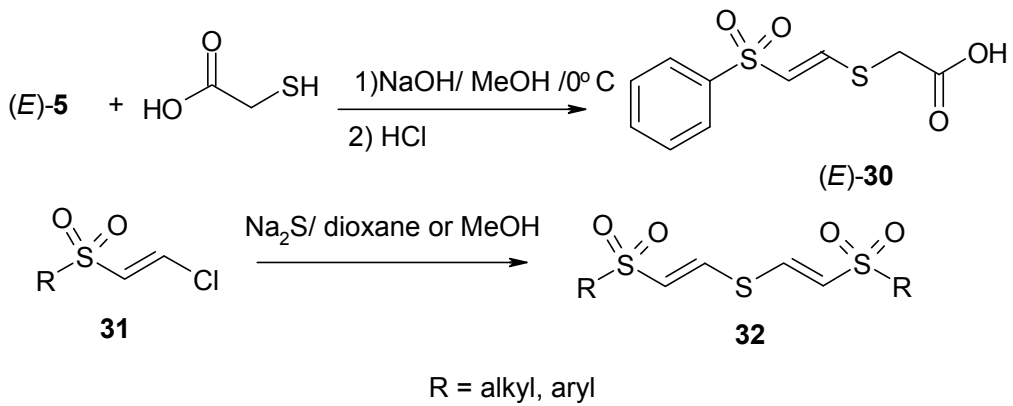

Suzuki reaction of 2-chlorovinyl sulfones with aromatic and heteroaromatic boronic acids was investigated [14]. The catalytic system 2-chlorovinyl derivative 5 or $34 / \mathrm{ArB}(\mathrm{OH})_{2} /$ solid $\mathrm{K}_{3} \mathrm{PO}_{4} / \mathrm{PdCl}_{2}(d p p f) \mathrm{CH}_{2} \mathrm{Cl}_{2}$ in the molar ratio of $1: 1.5: 2: 0.04$ was used as the most efficient one for the synthesis of products $\mathbf{3 3}$ and $\mathbf{3 5}$. The formation of arenes or hetarenes and homocoupling products of boronic acids (Ar-Ar) as minor products was also observed. 


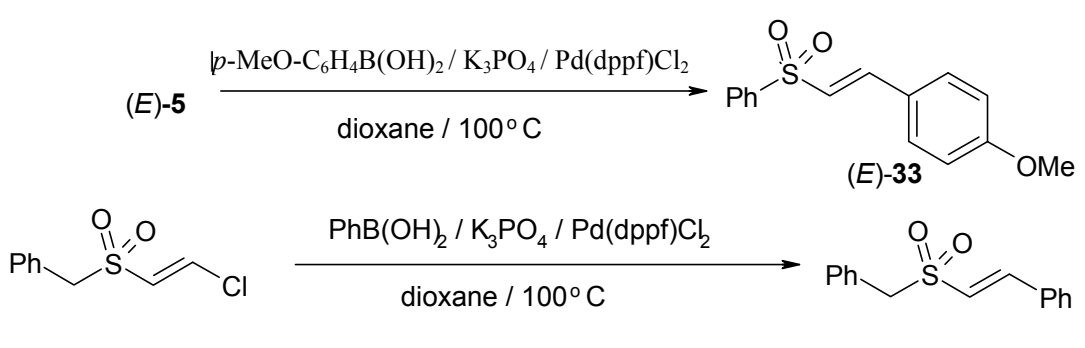

(E)-34

$(E)-35$

Interaction of chlorovinyl sulfones $\mathbf{3 6}$ with active methylene compounds (such as diethyl malonate or diethyl acetamidomalonate) in the presence of $\mathrm{NaH}$ leads to formation of the addition products 37 in $13-30 \%$ yields [40]. Experiments show, that the catalytic system solid $\mathrm{Cs}_{2} \mathrm{CO}_{3} / 18$-crown-6/ $\mathrm{CH}_{2} \mathrm{Cl}_{2}$ was non-effective in the reaction of addition of active methylene compounds to chlorovinyl sulfone 38 (Method A). Under these conditions the desired products were isolated only in yields up to $9 \%$. The synthesis of desired products 39 was carried out using triethylamine-catalyzed synthesis, too (Method B). Using triethylamine method, alkenes 39 were isolated in yields up to $87 \%$.

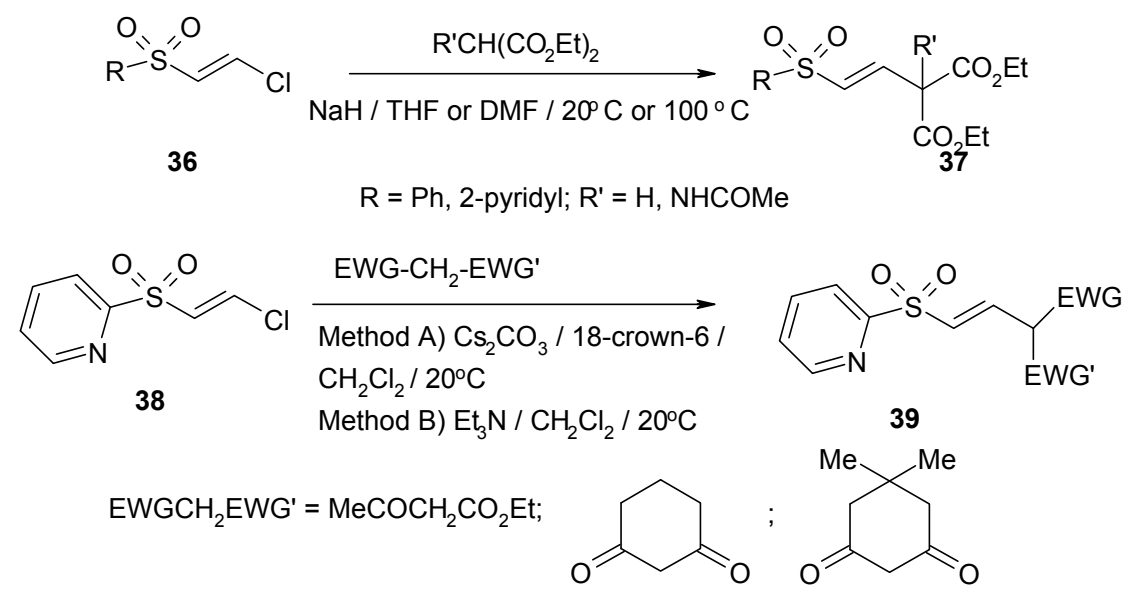

Finally, Takai-Hiyama-Nozaki-Kishi reaction of 2-chlorovinyl sulfones $\mathbf{4 0}$ with aldehydes in the system $\mathrm{CrCl}_{2} / \mathrm{NiCl}_{2} / \mathrm{THF}$ at room temperature afforded unsaturated sulfones 41 in 17-96\% yields [41].

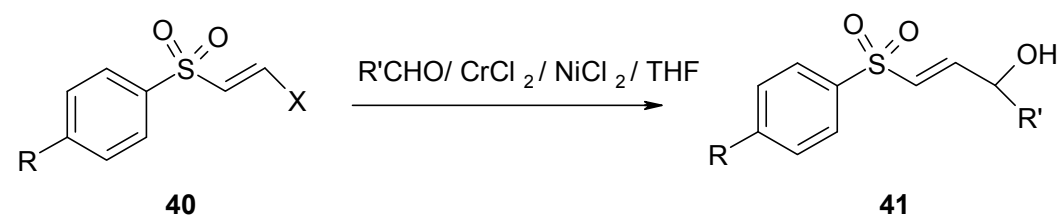

$X=\mathrm{Cl}, \mathrm{I} ; \mathrm{R}=\mathrm{H}, \mathrm{Me} ; \mathrm{R}^{\prime}=$ alkyl, aryl

\section{Radical 2-chlorovinylation}

Radical chlorovinylation of different alkyl iodides (for example, substrates 42 and 43) with (E)-1-chloro-2-ethanesulfonylethene (44) in the presence of lauroyl peroxide afforded the products 45 and 46, correspondingly [42]. 


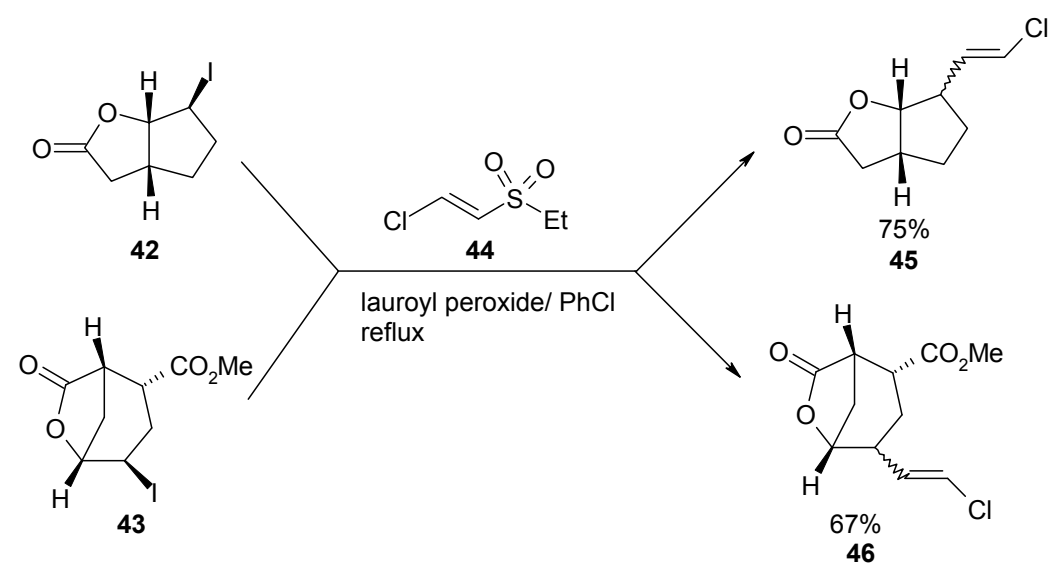

\section{Synthesis of heterocycles from 2-chlorovinylsulfones}

Synthesis of 2,3-dihydrofuran derivatives from 2-chlorovinyl sulfones was described in some articles [18, 24, 30, 43, 44]. Thus, interaction of epoxy alcohol $\mathbf{4 7}$ with chlorovinyl sulfone 5 afforded intermediate ether 48. Treatment of this product with lithium hexamethyldisilylamide (LiHMDS) in THF afforded dihydrofuran derivative $\mathbf{4 9}$ in $60 \%$ yield [44].

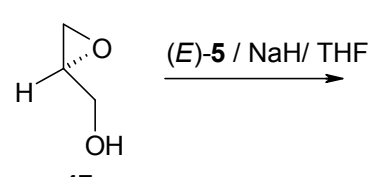

47

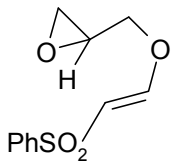

48
LiHMDS/ THF<smiles>CCCCOCCOC</smiles>

49

Novel method of synthesis of 1,3-dithiolanes and 1,3-dithianes 51 was elaborated [45]. Reaction of 2-chlorovinyl sulfones $\mathbf{5 0}$ with 1,2-ethanedithiol or 1,3-propanedithiol in the system $\mathrm{Et}_{3} \mathrm{~N} / \mathrm{PhMe}$ at $80{ }^{\circ} \mathrm{C}$ leads to formation of the desired products 51. Treatment of 2-chlorovinyl sulfone $\mathbf{5}$ with ethylene glycol in the presence of $\mathrm{NaH}$ in THF leads to 2-benzenesulfonylmethyl[1,3]dioxolane (52) [46].

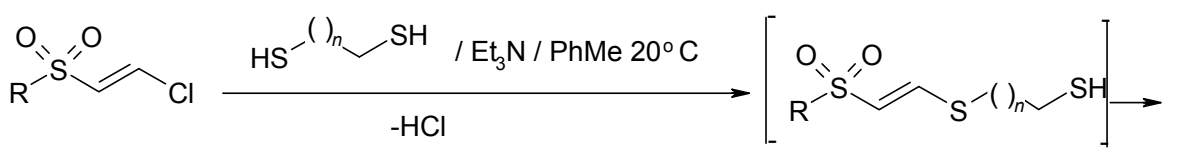

50

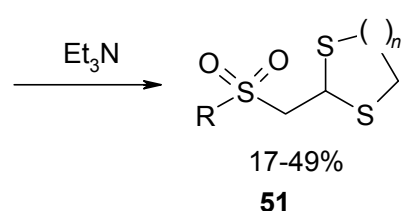

$\mathrm{R}=\mathrm{Ph}, \mathrm{CH}_{2} \mathrm{Ph} ; \mathrm{n}=1,2$
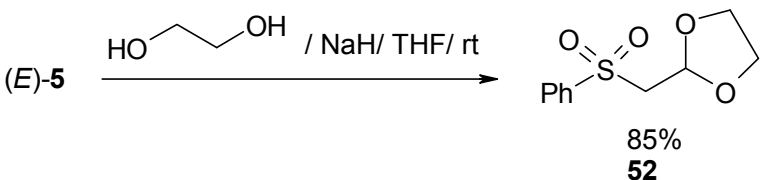
Treatment of chlorovinyl sulfone $\mathbf{5}$ with epoxy alcohol $\mathbf{5 3}$ in the presence of $\mathrm{NaH} / \mathrm{THF}$, followed by cyclization of an intermediate with lithium diisopropylamide (LDA) gives pyran 54 [18].

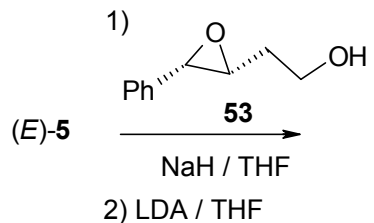<smiles>O=S(=O)(C1=COCCC1C(O)c1ccccc1)c1ccccc1</smiles>

1,2,3,4,4a,5-Hexahydropyrazino[2,1c][1,4]benzothiazine-6,6-dioxide (56) was obtained from 2-chlorovinyl sulfone $\mathbf{5 5}$ and ethane-1,2-diamine in monoethylene glycol ethyl ether [47]. Finally, polycyclic oxepine derivative 57 was obtained from 2-chlorovinyl sulfone 5 and $(R)$-2,2'-dihydroxy-1,1'-binaphthyl in the presence of $\mathrm{NaH}$ in THF [46].<smiles>O=S(=O)(/C=C/Cl)c1ccccc1Cl</smiles>

55

$(E)-5+$<smiles>Oc1ccc2ccccc2c1-c1c(O)ccc2ccccc12</smiles>

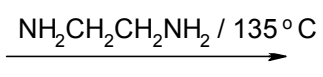<smiles>O=C1CC2CNCCN2c2ccccc21</smiles>

56<smiles>O=S(=O)(CC1Oc2ccc3ccccc3c2-c2c(ccc3ccccc23)O1)c1ccccc1</smiles>

57

\section{Acknowledgement}

This work was supported by the project of ESF Foundation of Latvia (Project N 2009/0197/1DP/1.1.1.2.0/APIA/VIAA/014).

\section{REFEREN CES}

1. Ogawa, A., Hirao, T. (1998). Highly selective thioselenation of carbon-carbon unsaturated bonds with a disulfide-diselenide binary mixture. Rev. Heteroatom Chem., 18 (1), 1-16.

2. Procter, D.J. (1999). The synthesis of thiones, selenols, sulfides, selenides, sulfoxides, sulfones and selenones. J. Chem. Soc., Perkin Trans. 1, 6, 641-668.

3. Procter, D.J. (2000). The synthesis of thiols, selenols, selenides, sulfoxides, selenoxides, sulfones and selenones. J. Chem. Soc., Perkin Trans. 1, 6, 835-871.

4. Oeckl, S., Paulus, W., Genth, H. (1976). Neue Mikrobizide. Ger. Pat. 2500265; C. A., 1976, 85, 159667q.

5. Singer, M.C. (1972). Herbicidal ureas. Ger. Pat. 2212044; C.A., 1973, 78, 58110n.

6. Diaz, P., Bernardon, J.M. (1999). Novel heteroethynylene compounds and pharmaceutical and cosmetic compositions containing same. PCT Int. Appl. WO Pat. 9950239, C.A., 1999, 131, 291281s.

7. Катаев, Е.Г., Маннафов, Т.Г., Самитов, Ю.Ю. (1975). Присоединение арилселенилхлоридов и арилсульфенилхлоридов к ацетилену. Ж. Орг. Хим., 11 (11), 2324-2327.

8. Fuson, R.C., Price, C.C., Bauman, R.A., Bullitt, O.H., Jr., Hatchard, W.R., Maynert, E.W. (1946). Levinstein mustard gas. 1. 2-Haloalkylsulfenyl halides. J. Org. Chem., 11 (5), 469474. 
9. Truce, W.E., Baudakian, M.M. (1956). Stereospecific reactions of nucleophilic agents with acetylenes and vinyl-type halides. 3. The reactions of cis-dichloroethylene, vinylidene chloride and vinyl bromide with sulfite ion. J. Am. Chem. Soc., 78 (12), 2752-2755.

10. Montanari, F. (1956). Ethynylation. 6. Stereoisomerism of thio and sulfonyl chloride vinylogs. Gazz. Chim. Ital., 86 (7), 735-746.

11. Montanari, F. (1956). Ethylenation reactions. 1. Addition of aromatic sulfochlorides to acetylene. Gazz. Chim. Ital., 86 (4), 406-414.

12. Rusell, G.A., Ngowiwatchai, P., Tashtoush, H.I., Pla-Dalmau, A., Khanna, R.K. (1988). Reactions of alkylmercurials with heteroatom-centered acceptor radicals. J. Am. Chem. Soc., 110 (11), 3530-3538.

13. Farina, V., Houck, S.I. (1991). Palladium-catalyzed synthesis of some new olefinic stannanes. J. Org. Chem., 56 (13), 4317-4319.

14. Ābele, E., Višnnevska, J. (2008). Synthesis and Suzuki reaction of (E)-chlorovinyl sulfides and sulfones. Latv. Ķìm. Žurn., 3, 263-267.

15. Višņevska, J. (2007). Synthesis and some catalytic reactions of (E)-chlorovinyl sulfides and sulfones. Latv. Kìm. Žurn., 4, 400.

16. Ochiai, M., Ukita, T., Fujita, E. (1983). A new synthesis of $\gamma$-hydroxyvinyl stannanes and silanes utilizing $\beta$-stannylvinyl and $\beta$-silylvinyl sulfones. Tetrahedron Lett., 24 (37), 40254028 .

17. Shimagaki, M., Koshiji, H., Oishi, T. (1983). 2-Halovinyl aryl sulfones: new coupling reagents for carboxamide formation. Phosphorus Sulfur Silicon., 16 (1/2), 45-58.

18. McCombie, S.W., Shankar, B.B., Ganguly, A.K. (1985). Cyclofunctionalization of epoxyalcohol derivatives 1. Discovery of functionalized carbon for stereospecific synthesis of dihydrofurans and dihydroxy acids. Tetrahedron Lett., 26 (51), 6301-6304.

19. Stefaniak, S.(1977). Reactions of aryl- $\beta$-chlorovinyl sulfones with tertiary amines. Rocz. Chem., 51 (3), 439-445.

20. Reddy, D.B., Babu, N.C., Padmavathi, V., Sumathi, R.P. (1999). A novel route for the synthesis of unsaturated oxo sulfones and bissulfenes. Synthesis, (2), 491-494.

21. Padmavathi, V., Reddy, B.J.M., Padmaja, A. (2005). A novel and simple route for the synthesis of 3,4-disubstituted pyrroles. J. Heterocycl. Chem., 42 (2), 333-335.

22. Reddy, D.B., Babu, N.C., Reddy, K.V., Padmavathi, V. (2001). A new route for the synthesis of bisunsaturated oxosulfones and bissulfenes under Friedel-Crafts conditions. Indian J. Chem., 40B (5), 416-418.

23. Zoller, T., Uguen, D., De Cian, A., Fischer, J. (1998). Efficient preparation of $E$ - $\beta$-iodovinylphenyl sulfone by Finkelstein reaction of a vinylic center. Tetrahedron Lett., 39 (44), 8089-8092.

24. Pelter, A., Ward, R.S., Little, G.M. (1990). Approaches to 2,6-diaryl-3,7-dioxabicyclo[3.3.0]octane lignans via asymmetric synthesis of dihydro- and tetrahydrofuran derivatives. J. Chem. Soc., Perkin Trans. 1, (10), 2775-2790.

25. Snider, B.B., Kirk, T.C., Roush, D.M., Gonzalez, D. (1980). Lewis acid-catalyzed ene reactions of ethynyl p-tolyl sulfone. J. Org. Chem., 45 (25), 5015-5017.

26. Stefaniak, S. (1966). $\beta$-Chlorovinyl mono nitroaryl sulfones. Poland Pat. 55012; C.A., 1969 , 70, 106199g.

27. Stefaniak, S. (1966). $\beta$-Chlorovinyl aryl sulfones. Poland Pat. 54937; C.A., 1969, 70, $28632 b$.

28. Stefaniak, S. (1978). Synthesis of monoazo disperse dyes containing $\beta$-chlorovinylsulfenyl groups. J. Pol. Chem., 52 (1), 19-24.

29. Maioli, L., Modena, G. (1959). Nucleophilic reactions in ethylene derivatives. 2. Mechanism of substitution of chlorine in 1-arylsulfonyl-2-chloroethylenes. Reaction with alcoholates. Gazz. Chim. Ital., 89 (7), 854-865.

30. Padwa, A., Bullock, W.H., Dyszlewski, A.D., McCombie, S.W., Shankar, B.B., Ganguly, A.K. (1991). Alkylation of 2-oxy-substituted 1-sulfonylalkyl and 1-sulfonylvinyl anions. New routes to functionalized carbocycles and dihydrofurans. J. Org. Chem., 56 (11), 3556-3564.

31. Ghersetti, S., Lugli, G., Melloni, G., Modena, G., Todesco, P.E., Vivarelli, P. (1965). Nucleophilic reactions in ethylenic derivatives. Part 8. Mechanisms of reactions of primary and secondary amines with arylsulfonylhalogenoethylenes. J. Chem. Soc., (3), 2227-2235.

32. Montanari, F. (1956). Ethylenation reactions. 4. 1,2-Bis(arylsulfonyl)ethylenes. Gazz. Chim. Ital., 86 (4), 428-431. 
33. Кравченко, В.В., Попов, А.Ф., Котенко, А.А. (1992). Взаимодействие транс-п-нитрофенил- $\beta$-хлорвинилсульфона с 4-аминопиридином в ацетонитриле. Ж. Орг. Хим., 28 (8), 1769-1770.

34. Visnevska, J., Abele, E., Belyakov, S., Shestakova, I., Jaschenko, E., Bridane, V., Popelis, J., Turovskis, I., Kalvinsh, I. (2011). (E)-Stereoselective conjugate addition of N-, S- and Senucleophiles to $(E)$-2-chlorovinyl sulfones and cytotoxicity of $(E)$-2-chlorovinyl sulfones and (E)-2-aziridinylvinyl sulfones. Phosphorus Sulfur Silicon (in press).

35. Modena, G., Todesco, P.E. (1959). Nucleophilic reactions in ethylene derivatives. 3. Mechanism of substitution of chlorine in 1-arylsulfonyl-2-chloroethylene with thiophenates and sodium azide. Gazz. Chim. Ital., 89 (7), 866-877.

36. Padmavathi ,V., Nagendra Mohan, A.V., Thriveni, P., Shazia, A. (2009). Synthesis and bioassay of a new class of heterocycles: pyrrolyl oxadiazoles/thiadiazoles/triazoles. Eur. J. Med. Chem., 44 (5), 2313-2321.

37. Aleksandrov, A.M., Yagupolskii L.M. (1970). Unsaturated sulfones containing fluorine. 8. Perfluoroalkyl vinyl sulfones. Zh. Org. Khim., 6 (2), 249-254.

38. Padmavathi,V., Sarma, M.R., Padmaja, A., Reddy, D.B. (2003). 2-Pyrazolines from 1,3dipolar cycloaddition of diazomethane to sulfonylethenes. J. Heterocycl. Chem., 40 (5), $933-$ 937.

39. Mannafov, T.G., Berdnikov, E.A. (2003). Arylselenovinyl sulfones. 2. Addition of benzeneselenols to aryl ethenyl sulfones. Russ. J. Org. Chem., 39 (8), 1292-1294.

40. Višnnevska, J., Ābele, E. (2011). Reactions of 2-chlorovinyl sulfones with C-nucleophiles. Latv. Kìm. Žurn., 1/2, 65-68.

41. Zoller, T., Uguen, D. (1999). An efficient procedure for preparing $\gamma$-hydroxy $\alpha, \beta$-unsaturated sulfones. Eur. J. Org. Chem., (7), 1545-1550.

42. Bertrand, F., Ouiclet-Sire, B., Zard, S.Z. (1999). A new radical vinylation reaction of iodides and dithiocarbonates. Angew. Chem., Int. Ed., 38 (13/14), 1943-1946.

43. Jung, M.E., Toyota, A., De Clercq, E., Balzarini, J. (2002). Synthesis and biological activity of methylene expanded oxetanocin. Monatsch. Chem., 133 (4), 499-520.

44. Jung, M.E., Toyota, A. (2000). Efficient synthesis of methylene-expanded oxetanocin nuclease analogues. Tetrahedron Lett., 41 (19), 3577-3581.

45. Вишневская, Ю., Абеле, Э., Лукевиц, Э. (2010). Новый метод синтеза бензол- и фенилметансульфонилметил[1,3]дитиоланов и [1,3]дитианов. ХГС, (9), 1326-1328.

46. Cossu, S., De Lucchi, O., Fabris, F., Ballini, R., Bosica, G. (1996). A Michael route to acetals and thioacetals: preparation of acetals (thioacetals) of 2-sulfonylacetaldehyde from alkynyl and other unsaturated aryl sulfones. Synthesis, (12), 1481-1484.

47. Bernotas, R.C., Dooley, R.J. (2010). Efficient syntheses of 1,2,3,4,4a,5-hexahydropyrazino[2,1-c] benzothiazine-6,6-dioxide. Tetrahedron, 66 (13), 2273-2276.

\section{2-HLORVINILSULFONU SINTĒZE UN REAKCIJAS}

J. Višņevska, E. Ābele

K O P S A VILK U M S

Apkopoti dati par 2-hlorvinilsulfonu sintēzi un reakcijām. Apskata pirmajā nodaḷā apkopotas 2-hlorvinilsulfonu sintēzes metodes izmantojot, oksidēšanas un eliminēšanas reakcijas. Tālākajā darbā apkopotas 2-hlorvinilsulfonu reakcijas ar dažādiem nukleofiliem reaǵentiem, kā arī jaunu heterociklisko savienojumu sintēze no 2-hlorvinilsulfoniem. 